\title{
REGIÓN VÝCHODNÉHO SLOVENSKA - SOCIOEKONOMICKÉ POSTAVENIE V SLOVENSKEJ REPUBLIKE A REGIONÁLNY ROZVOJ
}

\section{REGION OF EASTERN SLOVAKIA - SOCIOECONOMIC STATUS IN THE SLOVAK REPUBLIC AND REGIONAL DEVELOPMENT}

\section{Mgr. Martin ANGeloVil, PhD.}

\section{ING. VLADIMÍR BENL}

\author{
\begin{tabular}{l|l} 
Katedra geografie a aplikovanej geoinformatiky & Depart. of Geography and Applied Geoinformatics
\end{tabular} \\ Fakulta humanitných a prírodných vied Faculty of Humanities and Natural Sciences \\ Preǵovská univerzita v Preg்ve University of Presov \\ $\triangle$ Ul. 17. Novembra 1, 08116 Preǵsv, Slovak Republic \\ E-mail: angelovil.martin@gmail.com,benc@sfpa.sk,
}

\begin{abstract}
Anotácia
V príspevku bliğġe osvetQ̆jeme postavenie východného Slovenska v socioekonomickej ġruktúre ġátu. Skúmame jednotlivé socioekonomické ukazovatele a ukazovatele regionálneho rozvoja a opierame sa o práce publikované autormi voblasti výskumu regionálnych disparít. Vybranými ukazovateŏni sú ukazovatele trhu práce, ukazovatele príjmov vo forme priemernej nominálnej mesa! nej mzdy, regionálny hrubý domáci produkt a zahraniḷ né investície. Tieto ukazovatele povaǵijeme za kQ̣̆l ové pre analýzu socioekonomického postavenia regiónu v rámci Slovenska. Nağm cieQ̆m je zistenie reálneho postavenia a tendencií vývoja regiónu východného Slovenska a jeho dvoch celkov, Preǵovského a Koğického samosprávneho kraja, v socioekonomickej ğruktúre krajiny. Lasovo sa nag்a analýza bude prevaǵne opieraŠo údaje z rokov 2001 aǵ2013. Pri analýze obyvate@̆tva sme z dôvodu rozsahu príspevku boli nútení uviesŠiba odkazy na relevantné zdroje venujúce sa danej problematike. $V$ závere ponúkame súhrn zistených faktov a návrhy moǵnosti podpory regionálneho rozvoja skúmaného regiónu.

KŎílové slová

východné Slovensko, regionálne rozdiely, demografia, trh práce

\section{Annotation}

The status of Eastern Slovakia in the socio-economic structure of the country is explained in more detail in the article. We explore the various socio-economic and regional development indicators as well as article is based on work published by the authors within their research on regional disparities. Selected indicators are indicators of labor market, indicators of income in the form of average monthly wage, regional gross domestic product and foreign investment. These indicators are considered crucial for the analysis of socio-economic status of the region in Slovakia. Our aim is to analyze real status and development trends of the Eastern Slovakia region and its two administrative units: Pregivv and Kogice region in the socio-economic structure of the country. Analysis is based on data from 2001 to 2013. In a conclusion, we offer a summary of the facts and we provide recommendations for support of the regional development of the region.
\end{abstract}

\section{Key words}

eastern Slovakia, regional disparities, demographics, labor market

JEL classification: R12 


\section{Úvod}

Aj napriek svojej malej rozlohe je Slovensko krajina so znal nými regionálnymi rozdielmi. Východné Slovensko (región NUTS II), ktoré je administratívne rozdelené medzi Preġovský a Koğcký samosprávny kraj (regióny NUTS III), patrí medzi zaostalejg̉e regióny Slovenska. Príl in tohto stavu je viacero a je moǵné ich hădaŠ na nadnárodnej, národnej aj regionálnej úrovni. V celej Európskej únii vidíme západo-východný gradient rastu chudoby regiónov, ktorý sa v menğej mierke prejavuje aj na Slovensku. Za tento stav sú !̣iastoḷ ne zodpovedné historické okolnosti, ale tieǵ rozhodnutia vládnych orgánov, resp. realizovaná hospodárska politika gátu. Súl asne, globalizaḷ né tendencie, internacionalizácia, zvyğgvanie konkurencieschopnosti iných regiónov, zvyğjú nároky na konkurencieschopnosŠ miestnych podnikov a celého regiónu. Základným rysom dneg̉nej Európy je polarita medzi dynamickým rozvojom metropolitných oblastí a pomalým rastom území v okrajových oblastiach, vrátane východného Slovenska. A k hospodárskemu zaostávaniu regiónu prispieva skutol nosS̆ ǵe je rozdelený prírodnými bariérami (Tatry, Pieniny, Poloniny) a na východe vonkajg̉ou hranicou EÚ s Ukrajinou, ktorá sŠaǵuje pohyb osôb, tovaru, sluğieb a kapitálu. V poslednom období tieǵ na regionálny rozvoj a postavenie skúmaného regiónu v socioekonomickej ġruktúre krajiny vplývali dva významné faktory: vstup Slovenska do Európskej únie (EU) v roku 2004 a hospodárska kríza, ktorej nepriaznivé dôsledky sledujeme od jej prvých prejavov v roku 2008 aǵdo dneg̉ných dní.

\section{Metodika výskumu}

Pri analýze regiónu východného Slovenska je potrebné si uvedomovaŠjeho vnútorné rozdiely. Sú tu miesta s výrazným rastovým potenciálom, prevaǵne mestá ako Kog̉ce, Poprad, Preğbv li i Humenné a potom územia takmer vyQ̆ıdnené bez akejkoQ̆ek vyğgejej infrağruktúry a moǵnosక̌ami uplatnenia nielen pre mladých Q̆ıdí. Tieto regióny môǵeme nájs Š prevaǵne v prihranil ných oblastiach (bliǵğe napr. Angelovil 2010). Pri socioekonomických analýzach je vğak veŎni obtiaǵné získaŠ relevantné údaje o niğǵch hierarchických úrovniach, napr. pri okresoch sa ġatisticky nevykazuje viacero ekonomických charakteristík.

Na základe týchto skutol ností sa v naġej analýze budeme snaǵšs poukázaŠ na postavenie celého regiónu Východného Slovenska v rámci Slovenska a jeho porovnanie s inými oblasŠami (Stredné a Západné Slovensko a Bratislavský kraj, regióny NUTS II). V analýzach kde nebudú dostupné údaje za regióny NUTS II, uvádzame údaje za Preg̉ovský a Koğcký kraj a ich porovnanie k ostatným krajom, teda regiónom NUTS III. V tabuQ̣ách budeme graficky vy!̣ leŔovaŠhierarchické úrovne porovnávania (NUTS II a NUTS III). ÚroveŔceloġátna NUTS I bude v kaǵdej tabuăe.

Nag̉m cieŎm je zistenie súl asného postavenia regiónu Východného Slovenska a jeho dvoch celkov, Preg̉ovského a Koğckého samosprávneho kraja, v socioekonomickej ġruktúre krajiny. Tieǵ chceme analyzovaŠ trendy, teda !̣i sa socioekonomicky tento región vzmáha, alebo upadá. K naplneniu tohto cieă pouğ́jeme jednoduché gatistické analýzy výpoḷtu aritmetického priemeru vybraných ukazovateQv za dané ! asové obdobie, ktoré budeme porovnávaŠ nielen z priemerom krajiny, ale aj medzi jednotlivými regiónmi. Táto jednoduchá metóda nám poskytuje síce jednoduchý ale ucelený obraz o súl asnom postavení regiónu, ale aj o trendoch vývoja. Tieǵ chceme v závere ponúknuŠ nág pohăd na moǵnosti regionálneho rozvoja regiónu.

\section{Základná charakteristika územia}

Región východného Slovenska zaberá územie o rozlohe $15729 \mathrm{~km}^{2}$ (32\% rozlohy Slovenska) na ktorom k 31.12. 2012 ǵlo 1611407 obyvateQ̆v. Administratívne je región rozdelený na Koğcký a Preg̉ovský samosprávny kraj. Tie sa N̦alej delia na 24 okresov v ktorých je spolu 40 sídel so ġatútom mesta. Stupé́ urbanizácie sa pohybuje okolo $51 \%$ (2013). Región pregiel poḷ as svojej histórie zloğitým vývojom. Pozostáva z historických regiónov Spig̉a, Gariğa, Zemplína a Hontu. 
V nağom príspevku sa kvôli obmedzenému rozsahu, bliğg̉e nevenujeme analýze obyvateQ̆tva regiónu. Pre hlbg̉e poznanie tento problematiky odporúl ame napr. Bucher 2009, 2011a, 2011b; Klamár 2011, Rosil a kol. 2011; Rosil, KaŔuk 2009.

\section{Nezamestnanos S}

Dôleǵitým ukazovateŎm trhu práce je miera evidovanej nezamestnanosti. Jej Ăzdraváñ hodnota sa pohybuje na úrovni okolo 4 aǵ $6 \%$, ktorá zodpovedá normálnym pohybom pracovnej sily. NezamestnanosŠklesala od roku 2001 na celom Slovensku. V roku 2009 zaznamenávame jej nárast ako dôsledok hospodárskej krízy. Údaje za rok 2010 naznal ujú oğivenie trhu práce, no iba na jeden rok. V rokoch 2011 a 2012 uǵ môǵeme sledovaŠopätovný prepad vo vğetkých sledovaných regiónoch. V roku 2013 je zaznamenávaný mierny pokles nezamestnanosti predovġetkým v krajoch s najvyğg̉ou mierou nezamestnanosti. Jednoduchý aritmetický priemer miery evidovanej nezamestnanosti je najvyğğ práve $\mathrm{v}$ oblasti východného Slovenska. Z krajov majú najvyğg̣u priemernú mieru nezamestnanosti Banskobystrický, Kog̈ický a Preg̉ovský.

Tab. 1: Miera evidovanej nezamestnanosti v \% (NUTS I, II, III)

\begin{tabular}{|l|r|r|r|r|r|r|r|r|r|r|r|r|r|r|}
\hline \multicolumn{1}{|c|}{ Územie / rok } & 2001 & 2002 & 2003 & 2004 & 2005 & 2006 & 2007 & 2008 & 2009 & 2010 & 2011 & 2012 & 2013 & $\varnothing$ za obdobie \\
\hline Slovenská republika & 18,6 & 17,5 & 15,6 & 13,1 & 11,4 & 9,4 & 8,0 & 8,4 & 12,7 & 12,5 & 13,6 & 14,4 & 13,5 & 13,0 \\
\hline Bratislavský kraj & 5,8 & 5,2 & 4,0 & 3,4 & 2,6 & 2,3 & 2,0 & 2,3 & 4,4 & 4,6 & 5,4 & 5,7 & 6,2 & 4,1 \\
\hline Západné Slovensko & 17,5 & 15,6 & 13,6 & 10,8 & 8,6 & 6,6 & 5,4 & 5,7 & 10,2 & 9,9 & 10,8 & 11,6 & 10,9 & 10,6 \\
\hline Trnavský kraj & 15,5 & 13,0 & 11,1 & 8,8 & 7,2 & 5,2 & 4,3 & 4,3 & 8,4 & 8,2 & 8,9 & 9,4 & 9,2 & 8,7 \\
\hline Tren! iansky kraj & 12,7 & 10,9 & 9,9 & 8,1 & 6,8 & 5,2 & 4,5 & 5,0 & 10,1 & 9,5 & 10,0 & 10,9 & 10,7 & 8,8 \\
\hline Nitriansky kraj & 23,1 & 21,5 & 19,1 & 14,8 & 11,4 & 9,1 & 7,1 & 7,4 & 11,7 & 11,8 & 13,3 & 14,1 & 12,5 & 13,6 \\
\hline Stredné Slovensko & 19,9 & 19,1 & 17,9 & 15,3 & 13,8 & 11,6 & 9,8 & 10,2 & 14,9 & 14,8 & 15,8 & 16,7 & 15,4 & 15,0 \\
\hline Glinský kraj & 16,4 & 14,7 & 13,2 & 11,1 & 9,3 & 7,0 & 5,6 & 6,2 & 10,9 & 10,9 & 11,9 & 12,8 & 12,5 & 11,0 \\
\hline Banskobystrický kraj & 23,6 & 23,8 & 22,8 & 19,5 & 18,3 & 16,1 & 14,1 & 14,3 & 19,2 & 18,9 & 19,8 & 20,8 & 18,3 & 19,2 \\
\hline Východné Slovensko & 24,7 & 23,6 & 20,8 & 18,2 & 16,6 & 14,4 & 12,5 & 13,2 & 17,8 & 17,3 & 18,9 & 20,1 & 18,3 & 18,2 \\
\hline Preǵovský kraj & 24,0 & 23,0 & 19,6 & 17,5 & 15,8 & 13,7 & 12,1 & 12,9 & 18,3 & 17,8 & 19,0 & 20,7 & 19,4 & 18,0 \\
\hline Kog̈cký kraj & 25,6 & 24,3 & 22,2 & 18,9 & 17,5 & 15,2 & 13,0 & 13,5 & 17,3 & 16,8 & 18,8 & 19,6 & 17,2 & 18,4 \\
\hline
\end{tabular}

Najvyğg̉e hodnoty miery evidovanej nezamestnanosti dlhodobo dosahuje Banskobystrický kraj. Po Ŕom nasledujú kraje východného Slovenska: Preġovský a Kog̈cký. U oboch krajov zaznamenávame pokles nezamestnanosti v roku 2010, ale opätovné zvýġenie v nasledujúcich dvoch rokoch aǵ na úrové́z rokov 2002 a 2003.

Východné Slovensko ako celok malo v roku 2013 viac ako 18\% nezamestnanosŠ a zaznamenáva najvyğge hodnoty nezamestnanosti s pomedzi regiónov NUTS II pol as celého sledovaného obdobia.

Pri nezamestnanosti je jasne viditeăá priepasŠ medzi západným a juhovýchodným Slovenskom, keṆǵe k problémom Preg̉ovského a Kog̉ckého kraja je eğe potrebné prirátaŠ Banskobystrický kraj. Tri kraje juhovýchodného Slovenska majú v priemere o viac ako $7 \%$ vyğg̉u mieru nezamestnanosti ako kraje západu a v priemere o 5\% vyğg̉u mieru nezamestnanosti ako priemer Slovenska.

Problémom nezamestnanosti na Slovensku nie je len jej vysoká miera ale aj dØ̄kka trvania nezamestnanosti osôb, teda dlhodobá nezamestnanosక̌ Za dlhodobo nezamestnanú sa povaǵuje osoba, ktorá v priebehu 12 mesiacov nebola v platenom zamestnaní alebo samozamestnaní, je pripravená nastúpiSdo zamestnania a podniká kroky na získanie zamestnania.

Na základe zistení Ing̉itútu Zamestnanosti (Dlhodobá nezamestnanosŠ) bola v roku 2009 najvyğg̉a miera dlhodobej nezamestnanosti, z pomedzi 32 skúmaných krajín Európy práve na Slovensku, kde dosahovala mieru 6,49\%. Pri porovnaní regiónov NUTS I za tento rok, bolo Slovensko na 9 mieste. Postavenie východného Slovenska v tomto ukazovateli je najhorg̈e spomedzi regiónov Slovenska a tieǵ dosahuje nelichotivé výsledky aj medzi regiónmi v rámci EU. 
Dôsledky dlhodobej nezamestnanosti sa odzrkad@̆jú v niğǵgj moǵnosti zamestnania týchto osôb, zvyg̉ovaním nákladov na udróanie ich príjmu a financií vynakladaných na rekvalifikáciu. Dlhodobá nezamestnanosŠ je ! asto dôvodom sociálneho vylúl enia osôb a vedie k mnohým nepriaznivým skutol nostiam.

\section{Zamestnanos}

ZamestnanosŠje dôleğitým ukazovate@̆m nie len trhu práce, ale aj dôleǵitým indikátorom celkového bohatstva krajiny. Lím viac Q̊dí v produktívnom veku pracuje tým spolol nosŠ viac vytvorí. Aj preto je pre ekonómov miera zamestnanosti ! asto dôleğitejğm ukazovateØ̆m neǵ miera nezamestnanosti.

V roku 2012 bola celková miera zamestnanosti na Slovensku 56,8\%. V porovnaní regiónov NUTS II za rok 2012 je na tom najlepğe Bratislavský kraj, kde miera zamestnanosti dosahuje 66,3\%. Bratislavský kraj presahuje priemer Slovenska takmer o $10 \%$ a spolu s regiónom západného Slovenska (57,5\% zamestnanosŠ), sú jedinými regiónmi, ktoré dosahujú nadpriemerné hodnoty tohto ukazovateă na Slovensku. Stredné a východné Slovensko dosahujú rovnakú mieru zamestnanosti, (55,3\% resp. 55,1\%) !̣ím zaostávajú nie len za priemerom EU, ktorý bol v tomto roku na úrovni $68,5 \%$ (Eurostat), ale aj za priemerom Slovenska.

Pri zamestnanosti je na Slovensku z dôvodov jej nízkej úrovne dôleǵitý jej rast, ktorý naznal uje zvyg்vanie socioekonomickej úrovne regiónov. Vývoj rastu zamestnanosti hodnotíme za obdobie rokov 2001 aǵ 2013 na základe indexu zamestnanosti, ktorý udáva nárast alebo pokles oproti minulému roku. Jediným krajom, ktorého priemerný rast indexu nedosiahol ani $100 \%$, teda zaznamenal pokles, bol Banskobystrický kraj. Najpomalg̉e rástla zamestnanosŠ v Trenl ianskom, Preǵvskom a Kog̈ckom kraji. Priemer indexu zamestnanosti týchto krajov za uvedené obdobie nepresiahol hodnotu 100,35 lٕo znamená ǵe zamestnanosŠrástla veŎni pomaly. Tieǵ nárast zamestnanosti v Nitrianskom kraji je veŏni nízky.

Tab. 2: Index rastu zamestnanosti (rovnaké obdobie predchádzajúceho roka =100)

\begin{tabular}{|l|c|c|c|c|c|c|c|c|c|c|c|c|c|c|}
\hline \multicolumn{1}{|c|}{ Územie / rok } & 2001 & 2002 & 2003 & 2004 & 2005 & 2006 & 2007 & 2008 & 2009 & 2010 & 2011 & 2012 & 2013 & $\emptyset$ za obdobie \\
\hline Slovenská republika & 101,5 & 100,1 & 100,8 & 100,3 & 102,2 & 102,2 & 102,5 & 102,6 & 95,5 & 98,9 & 101,9 & 99,9 & 99,3 & 100,6 \\
\hline Bratislavský kraj & 101,5 & 101,4 & 101,7 & 99,7 & 102,0 & 103,6 & 103,3 & 103,2 & 98,8 & 99,0 & 100,8 & 101,9 & 97,0 & 101,1 \\
\hline Trnavský kraj & 102,4 & 101,5 & 101,2 & 103,2 & 105,0 & 105,1 & 103,1 & 102,5 & 95,4 & 99,7 & 100,7 & 101,6 & 101,1 & 101,7 \\
\hline Tren! iansky kraj & 101,5 & 100,9 & 100,8 & 100,3 & 101,6 & 101,3 & 101,4 & 102,1 & 94,0 & 97,7 & 104,9 & 96,1 & 97,6 & 100,0 \\
\hline Nitriansky kraj & 100,7 & 98,3 & 101,7 & 102,4 & 102,1 & 102,9 & 101,9 & 105,7 & 92,7 & 98,8 & 100,2 & 100,8 & 97,8 & 100,5 \\
\hline G̦linský kraj & 100,7 & 100,4 & 100,4 & 100,3 & 102,8 & 102,2 & 102,8 & 105,8 & 94,3 & 96,1 & 103,9 & 102,6 & 102,8 & 101,2 \\
\hline Banskobystrický kraj & 102,4 & 100,1 & 99,1 & 97,6 & 100,2 & 98,3 & 103,1 & 98,2 & 95,1 & 101,8 & 100,1 & 95,0 & 101,8 & 99,4 \\
\hline Preǵovský kraj & 99,9 & 100,0 & 100,0 & 99,8 & 102,3 & 100,2 & 101,8 & 99,4 & 95,8 & 99,4 & 103,4 & 102,0 & 99,3 & 100,3 \\
\hline Kog̈cký kraj & 103,1 & 97,8 & 100,9 & 99,5 & 102,0 & 103,3 & 102,0 & 102,6 & 95,5 & 98,8 & 102,1 & 97,6 & 99,2 & 100,3 \\
\hline
\end{tabular}

Vysoká nezamestnanosŠ spojená s vysokou mierou dlhodobej nezamestnanosti, nízka zamestnanosŠ a jej pomalý rast sa opäS koncentrujú prevaǵne na východnom Slovensku, z l oho vyplýva, ǵe najhorğa situácia na trhu práce je práve v tomto regióne.

\section{Priemerná nominálna mesal ná mzda}

Príjmy sú dôleğitým faktorom pôsobiacim na kvalitu ğivota obyvateQ̆v. Tieǵje moǵné na základe ich nerovnomerného prerozdeQ̆vania ur!̣ iŠekonomicky poddimenzované regióny. 
Tab. 3: Priemerná mesa! ná nominálna mzda v eurách

\begin{tabular}{|l|r|r|r|r|r|r|r|r|r|r|r|r|r|r|}
\hline Územie / rok & 2001 & 2002 & 2003 & 2004 & 2005 & 2006 & 2007 & 2008 & 2009 & 2010 & 2011 & 2012 & 2013 & $\varnothing$ za obdobie \\
\hline Slovenská republika & 410 & 448 & 477 & 525 & 573 & 623 & 669 & 723 & 744 & 769 & 786 & 805 & 824 & 644,3 \\
\hline Bratislavský kraj & 540 & 585 & 627 & 698 & 770 & 825 & 877 & 944 & 970 & 991 & 1001 & 1029 & 1049 & 838,9 \\
\hline Trnavský kraj & 379 & 414 & 444 & 487 & 534 & 584 & 636 & 676 & 689 & 705 & 735 & 736 & 745 & 597,2 \\
\hline Tren! iansky kraj & 371 & 404 & 423 & 462 & 502 & 544 & 583 & 630 & 635 & 657 & 687 & 724 & 750 & 567,1 \\
\hline Nitriansky kraj & 346 & 379 & 403 & 440 & 473 & 511 & 551 & 606 & 625 & 636 & 662 & 661 & 680 & 536,4 \\
\hline Gilinský kraj & 363 & 400 & 418 & 462 & 504 & 546 & 589 & 646 & 657 & 686 & 707 & 726 & 732 & 572,0 \\
\hline Banskobystrický kraj & 354 & 386 & 406 & 442 & 483 & 520 & 560 & 600 & 605 & 635 & 652 & 675 & 706 & 540,3 \\
\hline Preǵovský kraj & 328 & 359 & 378 & 416 & 438 & 468 & 498 & 546 & 573 & 594 & 608 & 613 & 636 & 496,5 \\
\hline Kog̉cký kraj & 391 & 433 & 469 & 512 & 557 & 595 & 627 & 672 & 684 & 716 & 726 & 735 & 758 & 605,8 \\
\hline
\end{tabular}

Zdroj: http://px-web.statistics.sk/PXWebSlovak/index.htm

Najniğǵa priemerná mesal ná nominálna mzda je dlhodobo v Preg̉ovskom kraji. Ako v jedinom kraji dosahuje hodnotu vyğgiu ako 600 eur iba v posledných troch rokoch a ako v jedinom kraji je za sledované obdobie priemer niǵǵ ako 500 eur. Oproti Bratislavskému kraju je takmer o polovicu niǵğa a v roku 2013 dosahuje iba 77\% celoslovenského priemeru. Vývoj v druhom administratívnom celku, tvoriacom východné Slovensko, teda v Kog̈ickom kraji, je pozitívnejğ. Priemerná mesaḷ ná mzda je $\mathrm{v}$ tomto regióne vygg̣a kvôli silnému zastúpeniu hutníckeho priemyslu v regióne, v podobe USS Kog̈ice a dobrému postaveniu mesta Kog̈ice ako centra obchodu, sluǵieb a cestovného ruchu. V Kog̉iciach navyǵe sídlia viaceré spolol nosti zamerané na informal né technológie a odvetvia s vyg்gu priemernou mzdou.

Vývoj rastu miezd dobre ilustruje index rastu. Je to ukazovateQ̆ ktorý udáva nárast mzdy oproti minulému roku. Jeho priemer za obdobie rokov 2001 aǵ 2013 je najvyğg v Trenl ianskom kraji a najniğǵ v Koğickom kraji. Preg̉ovský kraj má druhú najniǵg̉u mieru rastu aj s inými krajmi. V tomto ukazovateli sa opäŠukazuje zhorg̉ijúca sa situácia v Koğickom kraji.

Najhorg̈e z porovnania administratívnych celkov vychádzajú opäŠ regióny východného Slovenska. Preg̉ovský kraj, v ktorom najniǵğa priemerná mzda rastie veŎni pomaly a Kog̈cký kraj v ktorom je zaznamenaný najniǵǵ rast priemernej mzdy lo potvrdzuje jeho zhorǵijúce sa postavenie medzi regiónmi Slovenska. Východné Slovensko aj v ukazovateQ̆ch rastu zaostáva za ostatnými regiónmi a jeho pozícia v socioekonomickej ġruktúre krajiny sa zhorg்ije.

\section{Priame zahranil né investície}

Priama zahranil ná investícia predstavuje medzinárodnú investíciu, teda zámer subjektu jednej ekonomiky (priamy investor), získaŠ trvalý podiel $\mathrm{v}$ podniku so sídlom v inej ekonomike. Zjednoduğene povedané, ide o peniaze, ktoré preinvestuje zahranil ný podnikateŎna Slovensku.

Rozdelenie priamych zahranil ných investícií (PZI) je na Slovensku krajne nerovnomerné. Poḷas deviatich rokov (2003 ï 2011) bolo 64,87\% vg̉etkých PZI smerujúcich na Slovensko alokovaných do Bratislavského kraja a N̦alğch viac ako $18 \%$ na územie západného Slovenska. Iba 8,88\% z celkového podielu PZI prig̉o na východné Slovensko a na stredné Slovensko prig̉o 8,33\% PZI. Na úrovni krajov obstál najhorg̈e Preg̉ovský, kde za deväŠ rokov bolo sústredených iba 1,07\% PZI smerujúcich na Slovensko. Banskobystrický kraj dokázal pritiahnuŠ dvojnásobné mnoğstvo PZI na úrovni 2,37\% vğetkých PZI smerujúcich na Slovensko poḷ as deviatich rokov. Rozdelenie PZI podQ̆ krajov a oblastí na Slovensku ilustruje tabuăa ! . 4.

Tieto výrazné rozdiely sú spôsobené viacerými faktormi. Preg̉ovský kraj, aj napriek najniǵğej priemernej mzde, nedokázal prilákaŠğiadnu väl ğu zahranil nú investíciu. Dôleǵitú úlohu pri alokácii PZI zohrávajú aj vládne stimuly, ktoré dokáǵu presvedḷ iŠ investorov aby zaḷ ali podnikaŠ aj v nevyhovujúcich podmienkach. Ako príklad môǵeme uviesŠ KIA Motors, ktorej boli poskytnuté výrazné finan! né stimuly a prísQ̆b dobudovania diaĞice, ! i posledné rokovania vlády SR v centrále U.S. Steel a zníǵenie cien elektriny pre závod v Kog̉iciach. 
Tab. 4: Priame zahranil né investície na Slovensku v tis. eur (NUTS I, II a III)

\begin{tabular}{|c|c|c|c|c|c|c|c|c|c|c|}
\hline Územie / rok & 2003 & 2004 & 2005 & 2006 & 2007 & 2008 & 2009 & 2010 & 2011 & $\begin{array}{l}\mathrm{v} \% \mathrm{za} \\
\text { obdobie }\end{array}$ \\
\hline Slovenská republika & $\begin{array}{c}17238 \\
894\end{array}$ & $\begin{array}{c}20692 \\
595\end{array}$ & $\begin{array}{c}25086 \\
674\end{array}$ & $\begin{array}{c}29284 \\
029\end{array}$ & $\begin{array}{c}32411 \\
722\end{array}$ & $\begin{array}{c}36226 \\
446\end{array}$ & $\begin{array}{c}36469 \\
023\end{array}$ & $\begin{array}{c}37665 \\
095\end{array}$ & $\begin{array}{c}39641 \\
910\end{array}$ & 100 \\
\hline Bratislavský kraj & $\begin{array}{c}11786 \\
073\end{array}$ & $\begin{array}{c}13524 \\
247\end{array}$ & $\begin{array}{c}14496 \\
771\end{array}$ & $\begin{array}{c}18386 \\
927\end{array}$ & $\begin{array}{c}19979 \\
993\end{array}$ & $\begin{array}{c}23879 \\
091\end{array}$ & $\begin{array}{c}24169 \\
988\end{array}$ & $\begin{array}{c}25182 \\
386\end{array}$ & $\begin{array}{c}26806 \\
640\end{array}$ & 64,87 \\
\hline Západné Slovensko & 2529198 & 3432636 & 6261843 & 5612167 & 6165268 & 6278615 & 6641527 & 6466537 & 6203024 & 18,05 \\
\hline Trnavský kraj & 1201140 & 1861529 & 4445115 & 3218428 & 3302558 & 3251024 & 3439328 & 3109697 & 2769659 & 9,68 \\
\hline Tren! iansky kraj & 784101 & 956128 & 1141431 & 1217314 & 1562993 & 1628474 & 1734913 & 1803931 & 1847027 & 4,61 \\
\hline Nitriansky kraj & 543956 & 614979 & 675296 & 1176424 & 1299716 & 1399116 & 1467286 & 1552909 & 1586338 & 3,75 \\
\hline Stredné Slovensko & 1286078 & 1442806 & 1804461 & 2241673 & 3065373 & 3071942 & 3202199 & 3356840 & 3433365 & 8,33 \\
\hline G̣linský kraj & 819122 & 939189 & 1292007 & 1645263 & 2221821 & 2195419 & 2078715 & 2283702 & 2635227 & 5,86 \\
\hline $\begin{array}{l}\text { Banskobystrický } \\
\text { kraj }\end{array}$ & 466956 & 503616 & 512453 & 596409 & 843552 & 876523 & 891499 & 816171 & 997493 & 2,37 \\
\hline $\begin{array}{l}\text { Východné } \\
\text { Slovensko }\end{array}$ & 1637544 & 2292904 & 2523598 & 3043261 & 3201086 & 2996797 & 2687294 & 2916299 & 2999525 & 8,88 \\
\hline Preǵovský kraj & 253438 & 296839 & 298949 & 282361 & 249094 & 363904 & 425039 & 415900 & 369024 & 1,07 \\
\hline Kog̉cký kraj & 1384106 & 1996064 & 2224649 & 2760899 & 2951992 & 2632892 & 2262255 & 2500399 & 2630501 & 7,76 \\
\hline
\end{tabular}

Pozn. údaje za rok 2011 sú predbeǵné

Zdroj: http://www.nbs.sk/sk/statisticke-udaje/statistika-platobnej-bilancie/priame-zahranicne-investicie

\section{Hrubý domáci produkt}

Regionálny hrubý domáci produkt (HDP) na obyvateă je podielom dvoch ukazovateQ̆v ï regionálneho hrubého domáceho produktu (v ktorom sa uplatRuje kritérium zostavovania pod@̆ miesta pracoviska) a priemerného poḷ tu obyvateQ̆tva trvalo bývajúceho v danom regióne. Vo väl ġne regiónov nespôsobuje väl g̉e problémy porovnávanie týchto dvoch ukazovateQ̆v, zaloǵených na rozdielnych princípoch. V prípade regiónov s vysokou dochádzkou za prácou z okolitých regiónov, ktorými sú najmä regióny hlavných miest je tento ukazovateŎnadhodnotený. UkazovateŎregionálny HDP na obyvateă charakterizuje hospodársku prosperitu, resp. zaostalosડ̌ regiónu z hQ̆diska jeho výrobného potenciálu. Vhodný je na hodnotenie vyspelosti ekonomiky a intenzity rozvoja regiónu (statistics.sk).

Tvorba HDP na obyvateQ̆ v parite kúpnej sily (PKS) je výrazne diferencovaná. Ako pri iných ukazovateQ̆ch aj tu je zreteăný prepad v roku 2009 ako dôsledok hospodárskej krízy (viṆ Tab. ! . 5).

Tab. 5: Hrubý domáci produkt na osobu v PKS (NUTS I, II a III)

\begin{tabular}{|l|c|c|c|c|c|c|c|c|c|c|}
\hline Územie / rok & 2001 & 2002 & 2003 & 2004 & 2005 & 2006 & 2007 & 2008 & 2009 & 2010 \\
\hline Slovenská republika & 10368,5 & 11082,9 & 11499,8 & 12348,9 & 13547,7 & 14971,4 & 16825,1 & 18090,7 & 17064,2 & 17864,8 \\
\hline Bratislavský kraj & 22860,6 & 25049,2 & 25861,3 & 27900,9 & 32959,0 & 34900,6 & 39774,7 & 41702,6 & 41691,8 & 43063,3 \\
\hline Západné Slovensko & 9629,7 & 10122,8 & 10766,8 & 11709,8 & 12783,1 & 14821,7 & 16360,6 & 17295,8 & 16002,5 & 16734,2 \\
\hline Trnavský kraj & 10595,0 & 11084,5 & 11994,2 & 13027,9 & 14645,1 & 18235,5 & 20206,7 & 20743,0 & 18861,3 & 20078,2 \\
\hline Tren! iansky kraj & 9744,6 & 10130,2 & 10580,8 & 11436,4 & 11960,1 & 13994,4 & 15518,8 & 16394,4 & 15142,7 & 15823,3 \\
\hline Nitriansky kraj & 8786,4 & 9372,0 & 9971,8 & 10914,9 & 12026,0 & 12848,2 & 14050,5 & 15334,7 & 14462,9 & 14841,1 \\
\hline Stredné Slovensko & 8651,7 & 9309,6 & 9528,4 & 10081,3 & 10454,9 & 11613,0 & 13325,3 & 14732,0 & 13660,3 & 14564,5 \\
\hline G̣ilinský kraj & 8576,5 & 9056,5 & 9196,9 & 9997,3 & 11154,2 & 12135,6 & 14115,8 & 15765,7 & 14764,0 & 15826,1 \\
\hline Banskobystrický kraj & 8730,4 & 9574,9 & 9877,0 & 10169,7 & 9716,4 & 11059,6 & 12486,0 & 13632,0 & 12483,2 & 13215,4 \\
\hline Východné Slovensko & 7942,0 & 8406,6 & 8567,7 & 9106,6 & 9668,6 & 10367,4 & 11500,5 & 12718,7 & 11577,4 & 12069,6 \\
\hline Preǵgvský kraj & 6327,1 & 6862,4 & 6973,1 & 7390,7 & 7969,0 & 8192,4 & 9248,3 & 10619,4 & 9864,9 & 10103,7 \\
\hline Koġcký kraj & 9607,8 & 10001,7 & 10215,3 & 10879,8 & 11426,2 & 12618,2 & 13832,6 & 14894,8 & 13353,2 & 14109,3 \\
\hline
\end{tabular}

Zdroj: http://px-web.statistics.sk/PXWebSlovak/

Najvyg̈g̉e hodnoty dosahuje Bratislavský kraj, ktorý v roku 2010 dosahuje 241\% priemeru Slovenska v tomto roku. Prevyǵuje druhý najvyğǵ Trnavský kraj viac ako dvojnásobne a posledný Preg̉ovský kraj viac ako ġvornásobne. Regionálne rozdiely sú veŎni výrazné. Iba dva kraje prevyǵujú celoslovenský priemer ï Bratislavský a Trnavský. Najhorg̉e postavenie má Preg̉ovský kraj, kde hodnota HDP prevyǵje 10000 eur iba dva krát poḷ as sledovaného obdobia. V roku 2010 dosahuje hodnota HDP v Preg்vvskom kraji 56,5\% Slovenského HDP a Kog̉cký kraj dosahuje 78,9\%. 
Aritmetický priemer hodnôt Preg̉ovského kraja nedosahuje hodnotu 9000 euro ako u jediného kraja. Druhý najslabğ je Banskobystrický kraj. Východné Slovensko je medzi oblasŠami tradil ne najslabğe.

Zaujímavý je vývoj Kog̉ckého kraja, ktorý mal v roku 2001 tretiu najvyğġu hodnotu HDP na obyvateă. V priebehu desiatich rokov sa vğkk prepadol na ġeste miesto! Najpomalg̈e rástol HDP v Banskobystrickom (o 38\%) a Kog̈ckom kraji (o 41\%). Preg̉ovský kraj v roku 2010 dosiahol 147\% hodnoty roku 2001 a je tretí najpomalğ v raste HDP. Najrýchlejg̉e rástol HDP v Bratislavskom kraji (o 88\%) a Trnavskom kraji (o 81\%).

Pri prepol ítaní HDP v PKS na percentuálny podiel jednotlivých krajov sú rozdiely eg̉e zreteŏejg̉e (Tab. !. 6). Bratislavský kraj pol as celého obdobia prekral uje priemer Slovenska o viac ako 120\%. Navyǵ pol as celého sledovaného obdobia, aǵna rok 2008, zaznamenáva rast. Presne opal ný je vývoj v Preg்ovskom kraji a Kog̉ickom kraji. Preg̉ovský kraj, ktorý eg̉e v roku 2001 dosahoval $61 \%$ priemeru Slovenska, dosahuje v roku 2010 uǵ iba 56\% Slovenského priemeru a prepadol sa o 6\%. Kog̉cký kraj zaznamenal najhlbğ prepad, keN̦ v roku 2001 dosahoval takmer 93\% ale v roku 2010 uǵ iba 79\% priemeru Slovenska.

Tab. 6: Podiel HDP na osobu v PKS v regiónoch Slovenska (NUTS I, II a III)

\begin{tabular}{|l|c|c|c|c|c|c|c|c|c|c|}
\hline Územie / rok & 2001 & 2002 & 2003 & 2004 & 2005 & 2006 & 2007 & 2008 & 2009 & 2010 \\
\hline Slovenská republika & 100 & 100 & 100 & 100 & 100 & 100 & 100 & 100 & 100 & 100 \\
\hline Bratislavský kraj & 220,45 & 225,97 & 224,91 & 225,86 & 243,35 & 233,17 & 236,87 & 230,52 & 244,32 & 252,36 \\
\hline Západné Slovensko & 92,89 & 91,35 & 93,62 & 94,82 & 94,35 & 199,01 & 97,73 & 95,61 & 93,78 & 98,07 \\
\hline Trnavský kraj & 102,19 & 100,03 & 104,29 & 105,51 & 108,1 & 121,81 & 121,09 & 114,66 & 110,53 & 112,39 \\
\hline Tren! iansky kraj & 94,01 & 91,42 & 92,01 & 92,61 & 88,28 & 93,56 & 92,59 & 90,62 & 88,74 & 88,57 \\
\hline Nitriansky kraj & 84,76 & 84,57 & 86,7 & 88,37 & 88,75 & 85,77 & 83,72 & 84,77 & 84,76 & 83,07 \\
\hline Stredné Slovensko & 83,43 & 83,99 & 82,85 & 81,62 & 77,16 & 77,53 & 78,79 & 81,43 & 80,05 & 81,53 \\
\hline G̦ilinský kraj & 82,69 & 81,69 & 79,95 & 80,92 & 82,33 & 80,97 & 83,76 & 87,15 & 86,52 & 88,59 \\
\hline Banskobystrický kraj & 84,21 & 86,41 & 85,89 & 82,36 & 71,71 & 73,89 & 73,52 & 75,35 & 73,15 & 73,97 \\
\hline Východné Slovensko & 76,6 & 75,86 & 74,51 & 73,76 & 71,36 & 69,23 & 67,97 & 70,31 & 67,85 & 67,56 \\
\hline Preǵovský kraj & 61,01 & 61,91 & 60,63 & 59,84 & 58,8 & 54,7 & 54,58 & 58,70 & 57,81 & 56,56 \\
\hline Kog̈cký kraj & 92,69 & 90,27 & 88,86 & 88,14 & 84,35 & 84,27 & 81,83 & 82,33 & 78,25 & 78,98 \\
\hline
\end{tabular}

Zdroj: http://px-web.statistics.sk/PXWebSlovak/

Východné Slovensko ako oblasŠ NUTS II tieǵ zaznamenáva prepad v podiele HDP o 9\% poll as desiatich rokov. Prí! in tohto prepadu je viacero. Prvá je rýchle napredovanie západného Slovenska, predovg̉etkým Bratislavy a druhá je zaostávanie a stagnácia vývoja na východe krajiny.

\section{Záver}

Pri analýze postavenia východného Slovenska, Preġovského a Kog̈ckého kraja vo svetle vybraných ukazovateQ̆v je zrejmé, ǵe východné Slovensko je socioekonomickou perifériou Slovenska. Plne sa prejavuje západo-východný gradient chudoby a zhorǵijúce sa podmienky, vyplývajúce z okrajovej polohy územia, nie len voḷ i Slovenským ale aj medzinárodným centrám. Východné Slovensko sa od roku 1989 stáva perifériou nie len Slovenska, ale postupne celej EU. ĂKlincom do rakvyñ bol vstup krajiny do Schengenského priestoru, !o dodalo tomuto metaforickému konǵatovaniu reálnejg̈ie kontúry.

Regionálne rozdiely medzi krajmi sa prehlbujú a vytvárajú silné ekonomické jadro na západnom Slovensku a socioekonomickú perifériu juhovýchodného Slovenska. Nepotvrdzuje sa nepísané pravidlo, ǵe ekonomicky najslabg̉e regióny vykazujú najvyğgiu mieru rastu. Na Slovensku je to presne naopak.

Postavenie východného Slovenska ako regiónu NUTS II je podă nağej analýzy nepriaznivé. Pri evidovanej nezamestnanosti má východné Slovensko najvyğgiu mieru poḷ as celého sledovaného obdobia. Dlhodobá nezamestnanos Švykazuje iba o málo lepg̈e hodnoty ako stredné Slovensko. Miera zamestnanosti je rovnaká na východnom aj strednom Slovensku a zaostáva za priemerom Slovenska aj 
EÚ. Produktivita práce rastie najpomalg̉e, je hlboko pod priemerom Slovenska a dosahuje iba zlomok hodnoty Bratislavského kraja. Na východné Slovensko smerovalo iba 8,88\% PZI alokovaných na území Slovenska v rokoch 2003 aǵ2011. HDP na osobu v PKS nedosahuje na východnom Slovensku ani $68 \%$ Slovenského priemeru. Jediným ukazovateQ̆m, v ktorom je pozícia východného Slovenska obstojná je prirodzený prírastok. Túto pozíciu vğak zatieRuje najvyğge migral né saldo.

Z hQ̆diska postavenia dvoch samosprávnych celkov nachádzajúcich sa na východnom Slovensku, teda regiónov NUTS III Ï Preg̉ovského a Kog̉ckého kraja, je na tom lepg̉e Koġcký kraj. Preg̉ovský kraj mal vo väl ġne prípadov najhorg̈e postavenie medzi vğetkými krajmi, iba v niektorých ukazovateQ̆ch ho Ápredbeholñ Banskobystrický kraj. Pri priamych zahranil ných investíciách, priemernej mesal nej mzde a HDP na obyvateQ̆ v PKS je jeho zaostávanie za ostatnými krajmi najvýraznejg̉e. Problematická nie je len jeho pozícia najzaostalejg̉eho kraja, ale aj zhorǵbvanie tejto pozície a zväl ġjúci prepad oproti ostatným krajom. Eg̉e znepokojujúcejğ je prepad Kog̈ického kraja, ktorý vykazuje lepg̉e hodnoty vo vg̉tkých ukazovateQ̆ch ako Preg̉ovský kraj, ale znepokojujúce je zhorǵbvanie jeho pozície. Na zal iatku sledovaného obdobia bolo postavenie Kog̉ického kraja vo väl ğne sledovaných ukazovateQ̆vv výrazne lepg̈e ako na jeho konci.

Z naġej krátkej analýzy vybraných socioekonomických ukazovateQ̆v vidieŠ postavenie východného Slovenska ako najzaostalejǵj oblasti krajiny, ktorej postavenie sa navyğe zhorğje. Bratislavský kraj, spolu s Trnavským a Trenl ianskym krajom, tvoria jadro ekonomiky krajiny, Nitriansky a G̣ilinský kraj sú prechodom k najzaostalejğm krajom východu a juhu Slovenska - Banskobystrickému, Kog̉ickému a Preġovskému kraju. Medziregionálne rozdiely sa navyğe v rámci Slovenska sa zväl gijú a to jednak v dôsledku rýchleho rastu metropolitného regiónu Bratislavy a tieǵ negatívnym socioekonomickým trendom hlavne Preg̉ovského a Banskobystrického kraja.

Príl in zaostávania východného Slovenska je viacero. Prvá vychádza z územia, jeho polohy a charakteru, ktoré dlhodobo formovali rozvoj územia. Východné Slovensko bolo do socialistickej industrializácie prevaǵne poŎohospodárskou krajinou bez väl ğch priemyselných podnikov. V l ase socialistickej industrializácie sa rozdiely zotreli, ale vytriezvenie priğlo pri nástupe trhovej ekonomiky. Prezamestnanoš̌, strata trhov a neefektívne riadenie priniesli nezamestnanos $S_{\text {a }}$ neefektivitu práce ! o vrhlo východné Slovensko do pozície periférie národnej ekonomiky. Orientácia na veăké podniky v ! asoch socializmu, ktoré mali zabezpeḷ iŠ zamestnanosŠ celých okresov, sa ukázala ako krajne nevýhodná. Navyğe východné Slovensko vykazuje nízku hustotu veắých miest a rozdrobenú sídelnú ġruktúru v podobe veăkého pol tu malých obcí. Nezanedbateăým faktorom rozvoja je depresnosડ̌ priăhlých regiónov susediacich krajín. S regiónom východného Slovenska susedia najmenej rozvinuté regióny MaN̦arska, PoQ̆ka a Ukrajiny (pozri napr. Angelovil, Klamár, Ben!, 2011; Yehorovova, 2011), ktoré svojou ekonomickou silou, potenciálom i spoluprácou nedokáǵu stimulovaŠ vo väḷ ġej miere ekonomický rozvoj. Spolu s veăkým zastúpením rómskeho etnika a existenciou výraznej bariéry v podobe Schengenskej hranice, exentrickou, nevýhodnou polohou a nedostatkom veQ̆kej dopravnej infrağruktúry je východné Slovensko v znal nej konkuren!̣ nej nevýhode, ktorá naN̦alej prehlbuje jeho zaostávanie.

Moǵnosti nağartovania ekonomického rastu vidíme v návrhoch týchto rieġení:

- zefektívnenie regionálnej politiky a alokácia finan! ných prostriedkov do najmenej rozvinutých regiónov

- poskytovanie výrazných finan! ných stimulov pre investorov prichádzajúcich do najzaostalejğch regiónov

- dobudovanie veăkej dopravnej infrağruktúry (diaĞil nej siete) a napojenie na celoeurópsku diaĞil nú sieŠcez D1 a cez R4 (Mig̉kolc)

- zlepǵenie podnikateQ̆kého prostredia v na celom území so ǵpeciálnou formou pomoci pri podnikaní v najzaostalejğ́ch regiónech

- koordinácia rozvojových plánov na úrovni NUTS III a vytvorenie spolol ného rozvojového plánu pre NUTS II Východné Slovensko

- vytvorenie podnikateQ̆kých inkubátorov vo väl ğch mestách regiónu 
- zlepǵenie !̣ erpania finan! ných prostriedkov EÚ prostredníctvom cielenej pomoci starostom pri realizácií projektov

- zlepg̉Š spoluprácu obcí v uǵ existujúcich zdruǵeniach poskytnutím ǵkoliacich programov zameraných na podporu efektívneho riadenia zdruǵenia

Najvýznamnejğbu potrebou pohranil ného regiónu je vğk potreba podnietiŠ ġrukturálnu zmenu regionálnej ekonomiky smerom $\mathrm{k}$ rastu zaloğenému na zvyğovaní inoval nej a konkuren! nej schopnosti regiónu a v Rom pôsobiacich subjektov s cieQ̆m podporovaŠ udróateĞý rast príjmov, zamestnanosti a kvality ǵivota obyvateQ̆v. Jednou z priorít by mala byŠ v spolupráci s národnými vládami podpora dynamického podnikateQ̆kého prostredia priaznivého pre inovácie a mobilizácia prostriedkov pre vytváranie priaznivej investil nej a inoval nej klímy prostredníctvom regionálnych ğpecifických zdrojov (vedomosti, zruḷ nosti, kompetencie, .....). Je potrebné prehlbovaŠ integráciu a ukotvenie kđ̆ị ových priemyselných odvetví, ktoré zvygijú regionálnu a miestnu pridanú hodnotu. Príkladom môǵe byS sektorové i multisektorové sieŠvanie jednak miestnych dodávateQ̆kých reŠazcov a jednak sieŠovanie výskumu ï producentov ï uğ́vateQ̆v prostredníctvom koordinácie a interakcie medzi zúl astnenými subjektmi. Dôleǵitá je tieǵ medzinárodná spolupráca s transferom know-how, zapájanie sa regionálnych subjektov do medzinárodných inoval ných aktivít, ! o by malo podporiŠ vznik iniciatív vedúcich ku globálnej konkurencieschopnosti a zároveŔ k regionálnej relevantnosti. Na regionálnej úrovni je nutné nielen k tomu budovaŠinfrag̉ruktúru, ale vytváraŠrôzne nástroje. Je potrebné N̦alej budovaŠa zlepg̉ovaŠregionálny systém pre podporu podnikania a inovácií.

PodQ̆ náğho názoru bude, okrem vyğg̉e uvedených aktivít, veăni dôleǵité sústrediŠ sa na rozvoj území s najvyğğm potenciálom rastu ï miest $\mathrm{s}$ poḷ tom obyvateŎv nad 50 tisíc. Pre tieto mestá by mohol vzniknúŚ osobitný rámec podpory na národnej úrovni. Jeho cieØ̆om by mala byŠ podpora podnikania, prilákanie zahranil ných investorov, propagácia regiónov a efektívnej spolupráce s obcami blízko daného mesta.

\section{Literatúra}

[1] ANGELOVIL, M., (2010). Charakteristika priemyslu v slovenských okresoch slovensko-ukrajinského pohraniḷ ia. In Sborník pŚssp円kT z XXII. sjezdu Ḷeské geografické spole! nosti poŚádaného Ostravskou univerzitou v Ostrav门31. srpna - 3. záŚ 2010 ÁGeografie pro góvot ve 21. Stoletín. Ostrava: Ostravská univerzita v Ostravh pp. 500-504. [online]. [cit. 2014-2-20]. Dostupné z: 〈http://konference.osu.cz/cgsostrava2010/dok/Sbornik_CGS/Socioekonomicka_geografie/C>

[2] ANGELOVIL, M., KLAMÁR, R., BENL, V., (2011). Socio-ekonomické postavenie Východného Slovenska v Slovenskej republike a jeho regionálny rozvoj. In Vladimír Ben!, Svitlana Mytryayeva (eds.) Slovensko a Ukrajina: Rozvoj prihranil ných území (Regionálny rozvoj a cezhranil ná spolupráca). Preǵov/Uǵhorod: Výskumné centrum Slovenskej spolo! nosti pre zahranil nú politiku, n.o. ISBN 978-8089356-19-5.

[3] BUCHER, S., (2009). ōudský potenciál ako faktor rozvoja regiónu NUTS II - Východné Slovensko. In Zborník príspevkov z medzinárodnej konferencie ĂVýznam Q̆dského potenciálu v regionálnom rozvojiñ [CD/ROM]. Podhájska: Východoeurópska agentúra pre rozvoj. pp. 36-44. ISBN 978-80-970277-0-4.

[4] BUCHER, S., (2011a). Hodnotenie atribútov sídelnej ġruktúry regiónu NUTS II ï východné Slovensko. Geografická Revue, vol. 7, iss. 1, pp. 88 ï 111.

[5] BUCHER, S., (2011b). Popula! ná dynamika Koğckého a Preg̉ovského samosprávneho kraja v kontexte regionálneho rozvoja. Geografické informácie, vol. 15 iss. 1, pp. 31 ï 44.

[6] Dlhodobá nezamestnanos Š [online]. [cit. 2014-2-28]. Dostupné z: <http://www.iz.sk/sk/projekty/ukazovatele-za-EU/dlhodoba-nezamestnanost-nuts-2> .

[7] Employment rate in the EU27 fell to 64.6\% in 2009. [online]. [cit. 2014-1-15]. Dostupné z: <http://epp.eurostat.ec.europa.eu/cache/ITY_PUBLIC/3-04082010-BP/EN/3-04082010-BP-EN.PDF>

[8] Eurostat. [online]. [cit. 2014-3-15]. Dostupné z: 〈http://www.eurostat.com〉.

[9] HANZELOVÁ, E., (2007). Dlhodobá nezamestnanosŠv kontexte zmien sociálneho systému a trhu práce. [online]. [cit. 2014-3-20]. Dostupné <http://www.sspr.gov.sk/texty/File/vyskum/2007/Hanzelova/Hanzelova.pdf〉.

[10] MATLOVIL̦ R., KLAMÁR R., MATLOVIL̦OVÁ K., (2008). Vývoj regionálnych disparít zal iatkom 21. storol ia na Slovensku vo svetle vybraných indikátorov. Regionální studia, 2/2008. ISSN 1803-1471. 
[11] KLAMÁR, R., (2011). Vývoj regionálnych disparít na Slovensku s osobitným zreteØ̆m na regióny východného Slovenska. In Prírodné vedy. Folia geographica 18. Preġv: Preǵovská univerzita, Fakulta humanitných a prírodných vied. pp. 8 ï 88. ISSN 1336-6157.

[12] MATLOVIḶ R., MATLOVIḶOVÁ K., (2005). Vývoj regionálnych disparít na Slovensku a problémy regionálneho rozvoja Preg்osvského kraja. [online]. [cit. 2014-3-26]. Dostupné z: <http://www.fhpv.unipo.sk/ matlovicova/Region\%C3\%A1lne\%20disparity.pdf>.

[13] Ministerstvo výstavby a regionálneho rozvoja SR. Informa! ný systém výstavby a regionálneho rozvoja (ISVRR). Bratislava, [online]. [cit. 2014-3-25]. Dostupné z: http://www.ueos.sk/mvrr.sr/isvov.

[14] ROSIL, M. a kol., (2011). Regional socioeconomic indicators and ethnicity as predictors of regional infant mortality rate in Slovakia. International Journal of Public Health, vol. 56, iss. 55, pp. 523-531. ISSN 16618556. DOI 10.1007/s00038-010-0199-3.

[15] ROSIL,, M., KA@UK, J., (2009). Vplyv vybraných socio-ekonomických faktorov na mieru nezamestnanosti na úrovni malých území. Geografický !̣asopis, vol. 61, iss. 4, pp. 315-335. ISSN 00167193.

[16] Slovenská agentúra pre rozvoj investícií a obchodu (SARIO). Prílev a odlev PZI. Bratislava, [online]. [cit. 2014-2-15]. Dostupné z: 〈http://www.sario.sk/?prilev-a-odlev-pzi >.

[17] Ġatistický úrad SR. [online]. [cit. 2014-2-11]. Dostupné z:< http://www.statistics.sk >.

[18] Ġatistický úrad SR. Regionálna databáza. [online]. [cit. 2013-3-22]. Dostupné z: <http://pxweb.statistics.sk/PXWebSlovak/>.

[19] Zamestnanosડ̌ ï odkiaŎ prídu nové pracovné miesta? [online]. [cit. 2013-8-20]. Dostupné z: <http://www.noveidey.sk/kontakt/139-zamestnanost-odkial-pridu-nove-pracovne-miesta>.

[20] YEHOROVA, O., (2011). Sociálno-ekonomická situácia a regionálny rozvoj Zakarpatskej oblasti na celoǵátnej úrovni. In Vladimír Ben!, Svitlana Mytryayeva (eds.): Slovensko a Ukrajina: Rozvoj prihranil ných území (regionálny rozvoj a cezhranil ná spolupráca). Preg̉ov/Uğhorod: Výskumné centrum Slovenskej spolol nosti pre zahrani! nú politiku, n.o. ISBN 978-80-89356-19-5.

Príspevok je súḷaš̌ou rieġnia grantového projektu KEGA !̣. 024PU-4/2012 ĂGeokonfliktológia ï koncepcia výu!̣by nového predmetu a vypracovanie vysokoğgolskej u!̣ebniceñ (vedúci projektu: prof. RNDr. Robert İंok, PhD.).

Príspevok vznikol ako súḷaš podkladovej gúúdie pre Stratégiu rozvoja slovensko-ukrajinskej cezhrani! nej spolupráce do roku 2020. 